GARRIDO NOGUERA, Celso; PERES, Wilson. "Big Latin American industrial companies and groups." -- p. 129-150. -- En: CEPAL Review. Number 66 ( December 1998)- 


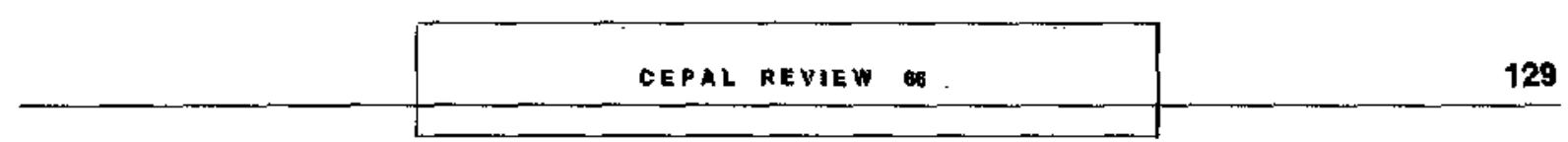

\section{Big Latin American industrial companies and groups}

\section{Colso Garrido}

Professor of the Autonomous Metropolitan

University, Azcapotzalco

Canpus, Mexico.

\section{Wilson Peres}

Chief, hodustrial and Technological Development Unit, ECLAC.
This article seeks to summarize the results of some studies on the structure and dynamics of the big domestically owned industrial companies and groups in five Latin American countries (Argentina, Brazil, Chile, Colombia and Mexico) and presents supplementary elements for placing them in an overall perspective. The studies include individual analyses of 46 leading companies (in Brazil, Chile and Colombia) and 15 economic groups with an industrial base (in Brazil and Mexico), together with aggregated studies of such groups in Argentina, Brazil and Mexico. In all cases, the studies were based on specially arranged interviews, the review of statistical and documentary information, and data already processed in the relevant literature. The time-scale of the studies ranges from the formation of some big companies and groups in the early years of the century or the period of dynamic import substitution industrialization, up to the changes under way in the second half of the 1990s. Analysis is centered on the last decade: i.e., since the time when the suructural reform processes were at their height in most of the countries whose big companies and groups are studied in this work. The article is divided into four sections. After the Introduction (seetion I), some summary details of the business context in the five countries studied are given (section II), after which the main structural features of the big companies and groups and their recent dynamics at the company, plant and group level are analysed (section III). Finally, in section IV, the main challenges facing public policies in this respect and the positions taken in the current debate on them are set forth. 


\section{I}

\section{Introduction}

In the second half of the 1990 s, the big privately owned industrial companies and groups (BIGs) occupy a strong position in the markets of the Latin American countries. This position is the result of processes which took place in the context of the structural changes undergone at the national and international level since the early 1980 s and has meant that the BIGs, along with the subsidiaries of transnational copporations, are now the biggest and most dynamic business units operating in Latin American industry. This dominant position has tended to be further strengthened by the privatization of the great majority of State-owned industrial enterprises, while smaller enterprises continue to face problems in modernizing their operations and speeding up their growth.

In terms of their competitiveness, the BIGs are in a transitional position, and in spite of their strength they are facing threats due to their structural characteristics, especially the fact that they are smaller than their international competitors and are located in sectors which are technologically mature and are growing relatively less rapidly in the world market. The growth rates of the BIGs have had difficulty in carrying forward the rest of the domestic economy with them, so that it is hard to describe their competitive position as reflecting a situation of real leadership. Although generally speaking the performance of the BIGs is successful, the rest of the local private companies are going through serious problems in most of the countries of the region, while the new configura-

D Ludovico Alcorta, Martine Dirven, Jorge Katz, Joseph Ramos and Ana San Sebastián made valuable comments and suggestions which permitted the correction of yarious errors and inconsistencies. This article is a summary version of chapter $I$ of Peres (1998).

1 The country studies are given in Peres (1998). In order to avoid repetition, whenever any of these five countries is mentioned this is understood to refer to the corresponding chapter in that book, unless otherwise stated. tions of the economy generated by the structural reforms are still in a state of flux and, in many cases, are strongly dependent on external variables.

The relative fragility and weak leadership capacity of the BIGs raise many doubts and give rise to much discussion with regard to their nature and their potential in relation to the economies where they operate. Most of the studies on the effects of the structural reforms have concentrated on the macroeconomic dimension, but few of them have analysed the situation of enterprises, and especially the BIGs, in this process. This omission is paradoxical, because in line with the policy approach which has predominated in the reforms, it might be expected that there would be growing interest in analysing the strategies and performance of enterprises, since it was expected that these would be the main economic agent in the context arising out of the reforms. Thus, the studies have not dealt with the determinants and forms of the processes of change among enterprises, other than noting the positive role which it was (rightly) expected that the increase in competition would play.

This article summarizes the results of several studies on the structure and dynamics of BIGs in five Latin American countries (Argentina, Brazil, Chile, Colombia and Mexico),' These studies include individual analyses of 46 leading companies (in Brazil, Chile and Colombia) and 15 industrial groups (in Brazil and Mexico), together with aggregate analyses of such groups in Argentina, Brazil and Mexico. ${ }^{2}$

\footnotetext{
${ }^{2}$ The criteria followed in selecting the companies and groups studied are described in detail in the corresponding chapters of Peres (1998). In most cases, the criteria were based on the possibility of having access to information and expert opinions on the importance of the companies and groups in question. The way the study was designed tended to concentrate attention on the BIGs which existed at the end of the period studied, which really means that the study covers the BiGs which were at least partly successful in adjusting to the new economic context. The fact that very few BIGs have gone out of business through bankruptcy or liquidation means that this skew is not important, however.
} 


\section{II}

\section{The business context}

Up to the early 1980 s, the linkages of the Latin American companies and economies with the outside world were determined by the conditions established under the economic order that arose after the war. This order was marked by heavy protectionism and the leading role played by the State in organizing and regulating economic growth through its promotion of import substitution industrialization.

In the course of their development, the economies of the region gradually began to display growing internal and external imbalances which led to "stop and go" economic growth. In this context, the biggest local enterprises sought a form of growth which was in keeping with the particular conditions imposed on them by the macroeconomic environment, the regressive income distribution, and the predominant orientation of their production towards relatively small domestic markets with low quality requirements. In particular, the relative smallness of the markets soon imposed a limit on their growth unless they diversified, and at the same time the possibility of bigh rates of profitability in new sectors promoted by the import substitution industrialization policy made it extremely attractive for them to venture outside their sectors of origin.

Thus, the big enterprises used vertical integration and the establishment of conglomerates as growth strategies, leading to the diversification of their investments into different economic sectors, including banking, against a background of growing concentration of State support and economic power in their favour. Vertical integration enabled them to cope with the problems of non-existent or incomplete markets, especially with regard to suppliets and subcontracting, which were particularly serious problems in under-developed countries closed to external supply. The incorporation of financial activities, for its part, enabled them to overcome problems of asymmetrical information and gain privileged access to credit, especially long-term credit.

Vertical integration and the formation of conglomerates made possible the establishment of large groups of enterprises (BIOs) ${ }^{3}$ able to develop and use specific assets (such as specialized labour) within their operations, reduce transaction costs, diversify the risks deriving from the uncertainty caused by economic instability, and provide the necessary guarantees when they needed financing on market terms. The utilization of economies of scale and of scope or field in respect of indivisible assets such as management capacity, corporate functions and specialized technology kept the advantages of their large scale alive even when markets were becoming deeper and their flaws were being reduced (Paredes and Sanchez, 1996).

The combination of the above elements explains why in Latin America, as in other late-developing regions, diversification has been an important strategy for maintaining and increasing the size of groups of enterprises (Bisang, 1996). However, growth based on vertical integration and conglomeration eventually came up against the limits imposed by the size of the domestic market and led to an extremely vulnerable type of diversification of investments. ${ }^{4}$

BIOS were thus the most advanced achievement bequeathed by import substitution industrialization in the area of domestic private enterprises and, together with the subsidiaries of transnational corporations and the big State enterprises, they formed the core of an industrial structure oriented towards the domestic

\footnotetext{
${ }^{3}$ The concept of "economic group" implies a set of operationally independent enterprises coordinated by a central body. Its activities may be concentrated on a certain type of product, diversified throughout a production chain with vertical integration, or organized in conglomerales operating in various sectors of economic activity. Very often, these forms of organization include financial institutions which, in some cases, are the dominant body in determining the common objectives. For a review of the theories on economic groups, see Granovetter (1994) and Bisang (1996).

${ }^{4}$ In spite of its costs in terms of specialization, the formation of conglomerates still has a role to play in Latin America, as is shown by the fact that, in contrast with the trend in developed countries, the shares of conglomerates in the region are quoted at a prenium over those of independent enterprises. Because of their lower capital costs and their greater access to the supply of management talent, conglomerates are considered to be in a better position to take advantage of new business opportunities. In particular, foreign investors seem to view conglomerates as country funds in which their diversification offers advantages in markets which are still of high risk (The Economist, 1997).
} 
market. Outside this dominant set of enterprises, there was a large number of small enterprises producing goods of very low technological content and making a very limited contribution to the national product, their main economic contribution being the significant number of jobs they generated.

In the 1980s, the Latin American economies reached such levels of imbalances in their production and financial activities that they were faced with the need to make structural reforms, seeking new growth paths through new types of linkages with the changing intemational scene. In general, the structural reforms tended to establish new orders marked by deregulation and liberalization of markets and opening up of the economy to the exterior. Consequently, in these countries there were changes not only in the characteristics and forms of macroeconomic op- eration but also in the production structures and the relations of the various economic actors, both with each other and with the actors in other countries and the world economy as a whole.

In this context, private enterprises came to be the decisive actors in economic growth. Now, more than 15 years after the beginning of the structural reforms, the BIGs continue to be of decisive importance in the economies of the countries of the region. Most of them occupy outstanding positions in the business universe of their countries, although the macroeconomic and institutional context is substantially different from that which existed when they were originally formed and they are very different, in terms of their organizational structures, strategies and types of performance, from those which existed in the early 1980 s.

\section{III}

\section{Business structure and dynamics}

It is hard to draw general conclusions from the results obtained in the studies on the BIGs of the five Latin American countries in question, both because of the different backgrounds and forms of evolution of the enterprises and the differences between the industries in which they operate, and because of the dissimilarities between the countries concerned with regard to their institutional and political evolution, size, geographical location and importance in the region.

Bearing these limitations in mind, the similarities and differences between the conditions, evolution and tendencies of the BIGs within the context of the two main dimensions of the analysis will be explored below. In the first section, a profile of their characteristics will be drawn on the basis of five variables: their origin, the predominant type of ownership, their relative size compared with other big industrial enterprises, the sectors of activity in which they operate, and the relations they have established between their domestic market and the international economy. In the second section, an analysis will be made of their processes of change, which means giving a schematic description of some of the main interactions between business strategies, the evolution of production patterns, and public policy actions, in which the impacts and challenges of external open- ness, globalization and regional integration occupy a leading place.

\section{Proflie of the big groups and enterprlses}

a) Origin

The BIGs which currently occupy a leading place in the Latin American business universe were mostly formed during the import substitution industrialization period, although some of them go back to the turn of the century, when the industrialization of the most advanced countries of the region began (Bunge y Born in Argentina, Alpargatas in Argentina and Brazil, the core of the Monterrey group in Mexico, Bavaria in Colombia, and Compañía de Cervecerías Unidas in Chile, among others). Their origin or rapid development during the import substitution industrialization period are particularly noteworthy in the case of the largest BIGs, which already occupied by the late 1970 s a position as important as that which they occupy today (for example, Votorantim in Brazil, ACINDAR in Argentina or Compañía de Acero del Pacífico in Chile), although all of them have had to carry out profound restructuring processes in order to maintain their position.

The origin of the main BIGs has been due fundamentally to three rationales. The two most important 
of these have been expansion from a strong business base developed around natural resources (for example, Bunge y Born developed from the marketing of cereals to the food industry) and growth through diversification in order to generate synergies from a basically industrial core (for example, the Monterrey group progressed from beer production to the production of glass bottles, metal sheets and corrugated cardboard). A third rationale, which is less frequent, corresponded to cases where the conglomeration was promoted by groups with a fundamentally financial base or connected 'with civil engineering or other services, which tended to acquire existing enterprises rather than creating new activities. Some outstanding examples of this are the groups generated around the Bradesco, Bamerindus, Garantía and Itaú banks and the Camargo Correa and Odebrecht construction enterprises in Brazil, or the industrial and financial groups reconstituled de facto in Mexico after the privatization of the commercial banking system in the early $1990 \mathrm{~s} .{ }^{5}$

In addition to the BIGs which arose before and during the import substitution industrialization process, there are new and sometimes very powerful BIGs which arose or developed in the course of the structural reforms carried out from the 1980s onwards. These new organizations have arisen from the privatization of traditional activities (ENERSIS in Chile) or from dynamic processes of conglomeration-building based on portfolio criteria (the Carso group in Mexico).

In the five countries studied, the top businesses in the second half of the 1990 s were not always the same as those of three decades earlier. The emergence of new BIGs and the disappearance or withdrawal from the group of leading enterprises of a few traditional groups such as Matarazzo in Brazil, Di Tella in Argentina, Cruzat-Larraín and Vial in Chile and the Gran Colombiano group in Colombia ${ }^{6}$ show that the composition of this group of top enterprises is not rigid. This suggests that there are different capacities of reaction to economic and political changes

\footnotetext{
5 By the late 1970 s important groups had been set up around the Banco Nacional de Mexico (BANAMEX) and the Banco de Comercio (BANCOMER), but these disintegrated when the private banking system. was nationalized in 1982 .

${ }^{6}$ There have been various different causes for the disappeararice of these groups. Matarazzo began to lose weight from the early 1960 s onwards because it could not cope with the inereased competition with its over-diversified and excessively vertically integrated structure. The crisis of Di Tella came on at the end of that decade when it could not cope with its problems of excessive
}

and that there is competition between capital blocs, in contradiction of the apparent "easy-going life of the oligopoly" which might be expected to exist in captive markets.

\section{b) Type of ownership}

Both the new bIGs and the traditional ones generally remain under personal or family ownership and are structured within formal or informal economic groups, from which they organize their relations of ownership, control, financing and resource allocation. The main reasons for this preference for keeping BIGs under personal or family control would appear to be the greater flexibility this provides for decision-making in unstable contexts, the greater facility for settling inheritance disputes when the founder dies, and the existence of a legal framework which does not effectively guarantee the rights of minority shareholders and gives rise to some uncertainty about respect for contracts (The Economist, 1997). Apart from these reasons, however, the predominance of family ownership and control seems to be typical of countries with levels of development like those of Latin America, and this becomes clear when it is noted that a similar phenomenon is observed in the economies of Southeast Asia (Koike, 1993). Many Blos continue to be closed companies, in the sense that their shares are not quoted on the stock market. Even when they are quoted, these enterprises only place a small percentage of their total equity on those markets, and the same is true of the increasingly numerous enterprises which place American Depositary Receipts (ADRs) on the United States stock markets. Generally speaking, these enterprises have been obliged to improve their provision of information, and some of them have had to dismember parts of their conglomerates into relatively independent corporations, although this has not fundamentally changed their forms of ownership and control.

diversification, inefficient scale, and insufficient cash flows for dealing with the modernization processes made necessary by competition (Bisang, Burachik and Katz (eds.), 1995). CruzatLarrain and Vial went bankrupt in 1983 when, because of the devaluation of the Chilean peso and the recession, their enterprises could not pay off the loans that their own banks had made to them with funds borrowed abroad. Finally, the Gran Colombiano group came to an and when the government decided to nationalize its controlling body, the Banco de Colombia, in 1984 because of some dubious transactions (Arbelaez, 1997). 
In some countries, such as Colombia, their reluctance to open up the ownership of their equity seems to have impeded the possibility of forming strategic associations with foreign investors, with consequent negative effects with regard to the transfer of production and management know-how. At the other extreme are Argentina and Mexico, where the number of such associations has increased markedly in the 1990s. The results of this have not been fully evaluated, but it would appear that in some cases the associations have only lasted a short time or have merely foreshadowed the acquisition of a substantial part of the local enterprise by the foreign partner, as in the case of the purchase of Cervecerfa Modelo (Mexico) by Anheuser Busch.

\section{c) Relative size}

The question of the size of BIGs and their relative position with respect to foreign corporations calls for a disaggregated study comparing what has happened in the five countries studied. For this purpose, information was used from three samples of the hundred largest domestic and foreign industrial enterprises in Latin America, ${ }^{7}$ with data for 1990, 1994 and 1996, respectively. Each of these samples was taken from a broader sample covering the 500 largest industrial and non-industrial enterprises of the region, published annually by the review América Economia. ${ }^{B}$ As noted in chapter 1 of Peres (1998), in 1996 the hundred largest industrial enterprises registered joint sales of US\$ 163.8 billion, equivalent to $29 \%$ of the sales of the 500 largest enterprises (US\$ 568 billion). The economic importance of the big enterprises is obvious when it is considered that the GDP of the region in that year was approximately US\$ 1700 billion. ${ }^{9}$

If we aggregate the information in the sample in question by country and type of ownership, we see that 99 of the 100 largest industrial enterprises in the region are privately owned (table 1), the Corporacion

\footnotetext{
${ }^{7}$ In the samples, the definition of ownership used was based on the criterion of the majority shareholder at the end of the calendar year.

${ }^{8}$ For some countries, especially Mexico, the sample includes both enterprises and groups of enterprises (holdings). As this procedure is not followed for all the countries, it would be wrong to claim that the unit of aralysis in the tables in this article is the BIO, although a number of them (especially those in Mexico) are indeed included. It should also be noted that the enterprises included in the sarnples vary from year to year, depending on their interest in participating.
}

Venezolana de Guayana (CVG) being the only Stateowned enterprise registered. The numerical balance between domestic and foreign-owned private industrial enterprises is also noteworthy, but this conclusion must be subject to reservations in the light of the structure of sales in the sample (table 2).

Thus, whereas domestically-owned private enterprises accounted for $40.2 \%$ of total sales in 1996 , the share of foreign-owned enterprises was substantially greater $(57.3 \%)$, while the presence of Stateowned enterprises was very small $(2.5 \%) .{ }^{10} \mathrm{~A}$ noteworthy feature in this picture is also the large average size of the enterprises concerned. In 1996, the average domestic enterprise in the sample had sales of US\$ 1345 million, while the foreign-owned enterprises averaged US $\$ 1879$ million. Naturally, these data do not reflect the economic power of each of these groups. Although the size of the domestic enterprises may be underestimated because not all the enterprises of the groups to which they belong are taken into account, the great majority of the big foreign firms in the region are subsidiaries of giant world corporations.

At the individual country level, there are various different situations. Brazil and Mexico account for $75 \%$ of the big industrial enterprises of the region, with Brazil having the larger share. As regards the balance between domestic and foreign-owned private firms, the latter predominate in Brazil, while in Mexico, Argentina and Colombia there are different degrees of relative balance between the two types of firms and in Chile there are only domestic large private enterprises.

In order to complete our consideration of the scale of the big Latin American industrial enterprises, it is worth comparing them with the big international

9 Some reservations should be made regarding the significance of sales as an indicator of the size of enterprises. Firstly, these amounts may be overvalued because of the level of the real exchange rate prevailing in the region, Secondly, these values underestimale the importance of domestic private enterprises because they do not include all the economic groups in which these are organized. Thirdly, insofar as the sample includes holdings (almost all of them Mexican), there is a risk of duplication. Since it is not possible to estimate the sign of the negative effect of these three skews, the data in the tables derived from the samples should be viewed with caution and taken as merely indicative.

${ }^{10}$ By way of comparison, it is worth noting that in 1996, among the 500 biggest enterprises in all sectors of activity, 276 domestic private enterprises accounted for $42 \%$ of sales, 161 foreignowned enterprises for $29.5 \%$, and 63 State-owned enterprises for 28.5\% (América Econtomia, 1997, p. 152). 
TABLE ?

Latin Amarlca: Ownershlp of the 100 largest industriaf enterprises, 1983

(Number of enterprises)

\begin{tabular}{|c|c|c|c|c|}
\hline & State enterprises & Domestic private enterprises & Foreign enterprises & Total \\
\hline Brazil & 0 & 17 & 23 & 40 \\
\hline Mexico & 0 & 18 & 17 & 35 \\
\hline Argentina & 0 & 7 & 8 & 15 \\
\hline Colombia & 0 & 2 & 2 & 4 \\
\hline Chile & 0 & 2 & 0 & 2 \\
\hline Yenezuela & 1 & 3 & 0 & 4 \\
\hline Total & $I$ & 49 & 50 & 100 \\
\hline
\end{tabular}

Source: Prepared by the authors on the basis of data given in chapter 1 of Peres, 1998.

TABLE 2

Latin America; Characterletics of the 100 largest

industrlal enterprises, by type of ownership, 1996

\begin{tabular}{|c|c|c|c|c|}
\hline Type of enterprise & Number of enterprises & $\begin{array}{c}\text { Sales (millions } \\
\text { of dollars) }\end{array}$ & $\begin{array}{l}\text { Average sales per } \\
\text { enterprise } \\
\text { (millions of dollars) }\end{array}$ & $\begin{array}{l}\text { Breakdown } \\
\text { of sales } \\
\text { (percentages) }\end{array}$ \\
\hline Domestic private & 49 & 65898 & 1345 & 40.2 \\
\hline Foreign & 50 & 93953 & 1879 & 57.3 \\
\hline State-owned & 1 & 4000 & 4000 & 2.5 \\
\hline Total & 100 & 563851 & 16,38 & 100.0 \\
\hline
\end{tabular}

Source: Prepared by the authors on the basis of data given in chapter 1 of Peres, 1998.

corporations. On the basis of the information on the 500 biggest world firms given in Fortune magazine, we see that the total sales of the 100 biggest (domestic and foreign-owned) industrial enterprises in Latin America in 1996 was less than the income of the world's largest corporation (General Motors), which came to US\$ 168.4 billion in that year. ${ }^{11}$ The biggest private industrial enterprise ever recorded in the region was a joint venture between Ford and Volkswagen (Autolatina) in Brazil, which was dissolved in 1994. Even so, this enterprise, with its annual sales of almost US\$ 10 billion, was only in the last places among the biggest world-level enterprises. ${ }^{12}$ No do-

\footnotetext{
11 Information taken from the web site http:twww,pathfinder. comfortune $500 \backslash 500$ list.html.

${ }^{12}$ In order to give this information its due weight it should be borne in mind that, as already noted, the phenomenon of conglomeration is not fully registered in the sample, and this true both of domestic private firms and foreign corporations which have large subsidiaries in a number of countries of the region. For both sypes of enterprises, consolidating all their sales would qualify them for inclusion among the lower levels of the world's largest corporations.
}

mestic private industrial enterprise in Latin America had sales anywhere near that level in 1996. ${ }^{13}$

\section{d) Sectors of activity}

A third feature of BIGs which is worth stressing concerns the sectors of activity in which they operate and their weight within them. Table 3 gives data for 1996 on the five biggest enterprises in 19 industrial sectors, prepared on the basis of the sample of the 500 biggest enterprises given in América Economía and already referred to earlier.

The first thing that we see from the table is the economic concentration that exists in Latin American industry. In the 19 industrial sectors in question, the 83 (domestic and foreign-owned) enterprises which qualify among the five biggest in each sector had sales of US\$ 122 billion and provided almost 780,000 jobs in 1996, when the gross value of industrial pro-

\footnotetext{
${ }^{13}$ In 1996 there were no private non-financial enterprises among the seven Latin American companies figuring in the corresponding list (The Ecoromist. 1997, p. 7).
} 
TABLE 3

Latln Amerlca: The five largest enterprises in 19 Industrlal sectors, 1996

\begin{tabular}{|c|c|c|c|c|c|c|}
\hline Sectorienterprise " & Country & Ownership $^{b}$ & $\begin{array}{c}\text { Sales } \\
\text { (millions } \\
\text { of dollars) }\end{array}$ & $\begin{array}{l}\text { Share of } \\
\text { dornestic enter- } \\
\text { prises in sales of } \\
\text { the five largest } \\
\text { enterprises }\end{array}$ & $\begin{array}{l}\text { Number } \\
\text { of workers }\end{array}$ & $\begin{array}{c}\text { Exports } \\
\text { (millions } \\
\text { of dollars) }\end{array}$ \\
\hline Sofl drinks and beer & & & & 100.0 & & \\
\hline Femsac $^{c}$ & Mexico & DP & 2558.7 & & 35937 & 55.8 \\
\hline Polar ${ }^{\mathrm{c}}$ & Venezuela & DP & 1700.0 & & 18000 & $\ldots$ \\
\hline Modelo & Mexico & DP & 1548.4 & & 38757 & 290.7 \\
\hline Brahma & Brazil & DP & 1541.1 & & 4858 & $\cdots$ \\
\hline Petrochemicals & & & & 100.0 & & \\
\hline Alpek & Mexico & DP & 1546.9 & & 5876 & $\cdots$ \\
\hline Copene & Brazil & DP & 1130.7 & & I 017 & $\ddot{m}$ \\
\hline Cydsa ${ }^{e}$ & Mexico & DP & 861.7 & & 10481 & 400.2 \\
\hline Copesul & Brazil & DP & 594.8 & & 743 & 64.9 \\
\hline Glass & & & & 100.0 & & \\
\hline Vitro $^{c}$ & Mexico & DP & 2317.0 & & 33428 & 758.0 \\
\hline Steel & & & & 80.4 & & \\
\hline CSN & Brazil & DP & 2169.7 & & 12532 & 579.8 \\
\hline Grupo Acerero del Norte ${ }^{c}$ & Mexico & DP & 1739.0 & & 23869 & 522.9 \\
\hline Ispat Mexicana & Mexico & $\mathrm{F}$ & 1650.2 & & 4083 & 639.5 \\
\hline Usiminas & Brazil & DP & 1605.8 & & 9210 & 333.4 \\
\hline Hylsamex $c$ & Mexico & DP & 1273.5 & & 7623 & 235.0 \\
\hline Auto parts & & & & 76.8 & & \\
\hline Desc $^{c}$ & Mexico & DP & 1576.7 & & 18880 & 582.6 \\
\hline Robent Bosch & Brazil & F & 934.0 & & 10829 & 266.1 \\
\hline Unik & Mexico & DP & 579.7 & & 9816 & $\ldots$ \\
\hline Iochpe-Maxion & Brazil & DP & 466.2 & & 5082 & 98.9 \\
\hline Gnupo Industrial Saltilio ${ }^{c}$ & Mexico & DP & 465.2 & & 10285 & 102.9 \\
\hline Textsles & & & & 74.1 & & \\
\hline Alpargatas & Argenting & $\mathrm{F}$ & 421.3 & & 2166 & ... \\
\hline Alpargates Santista & Brazil & DP & 416.7 & & 5196 & - \\
\hline Grupo Synkro ${ }^{c}$ & Mexico & DP & 399.7 & & $\ldots$ & 40.1 \\
\hline $\begin{array}{l}\text { Săo Paulo Alpargatas } \\
\text { Agro-industries }\end{array}$ & Brazil & DP & 389.7 & 71.2 & 11777 & $\ldots$ \\
\hline Cargill & Argentina & F & 1308.0 & & 1800 & 1066.3 \\
\hline Molinos Rla de la Plata & Argentina & DP & 1215.4 & & 4600 & 373.8 \\
\hline Coamo & Brazil & DP & 712,9 & & 3179 & 386.8 \\
\hline Nidera Argentina & Argentina & DP & 674.5 & & 840 & 482.6 \\
\hline $\begin{array}{l}\text { La Plata Cereal } \\
\text { Cement }\end{array}$ & Argentina & DP & 631.9 & 69.0 & 568 & 446.3 \\
\hline Cemex & Mexico & DP & 3488.7 & & 20527 & 125.3 \\
\hline Apasco & Mexico & $\mathbf{F}$ & 525.5 & & 2607 & 7.9 \\
\hline Santa Marina & Brazil & $\mathbf{F}$ & 373.1 & & 3018 & $\ldots$ \\
\hline Vencemos & Venezurela & $\mathbf{F}$ & 340.0 & & 4000 & 91.5 \\
\hline Cebrace & Brazil & $\mathbf{F}$ & 331.6 & & $\cdots$ & - \\
\hline Pulp and paper & & & & 66.4 & & \\
\hline Papeles y Cartones (CMPC) & Chile & DP & 1265.0 & & $\cdots$ & 298.5 \\
\hline Kimberly-Clark & Mexico & $\mathrm{F}$ & 1198.0 & & 8013 & 70.5 \\
\hline Klabin & Brazil & DP & 564.7 & & 6337 & $\ldots$ \\
\hline Aracruz & Brazil & DP & 536.7 & & 2547 & 490.0 \\
\hline Machinery and equipment & & & & 57.6 & & \\
\hline Condumex & Mexico & DP & 787.6 & & 11554 & $\cdots$ \\
\hline $\begin{array}{l}\text { Asea Brown Boveri (ABB) } \\
\text { Empresa Brasileira de }\end{array}$ & Brazil & $\mathbf{F}$ & 477.7 & & 3006 & $\cdots$ \\
\hline Compressores (Embraco) & Brazil & DP & 410.7 & & 6006 & $\ldots$ \\
\hline $\begin{array}{l}\text { Caterpillar } \\
\text { Foodstufts }\end{array}$ & Brazil & $\mathbf{F}$ & 406.2 & 48.1 & 2338 & $\cdots$ \\
\hline Nestlé & Brazil & $\mathrm{F}$ & 3591.8 & & 17150 & 123.0 \\
\hline Sabritas & Mexico & $\mathbf{F}$ & 2600.0 & . & $\ldots$ & $\ldots$ \\
\hline
\end{tabular}




\begin{tabular}{|c|c|c|c|c|c|c|}
\hline Copersucar & Brabil & $\mathrm{DP}$ & 2033.7 & & 1107 & 380.8 \\
\hline Bimbo & Mexico & $\mathrm{DP}$ & 1983.2 & & 55148 & $\ldots$ \\
\hline Ceval & Brazil & DP & 1729.5 & & 13828 & 735.6 \\
\hline $\begin{array}{l}\text { Housebold appliances and } \\
\text { electronics }\end{array}$ & & & & 46.0 & & \\
\hline Multibrárs & Brazil & DP & 1804.5 & & 11101 & 63.9 \\
\hline Xerox & Brazil & $F$ & 1630.0 & & 6000 & 66\rfloor$. \\
\hline Itautec Phikco & Brazil & $\mathrm{DP}$ & 929.9 & & 4887 & $\ldots$ \\
\hline Ericsson & Brazil & $\mathrm{F}$ & 806.8 & & 2330 & $\cdots$ \\
\hline Mabe & Mexico & $\mathrm{F}$ & 772.9 & & 13120 & 30.1 \\
\hline Tobaces & & & & 39.4 & & \\
\hline La Moderna & Mexico & DP & .1883 .9 & & 11249 & 55.9 \\
\hline Souza Cruz (BAT) & Brazil & $\mathbf{F}$ & 1583.2 & & 8920 & $\cdots$ \\
\hline Massalin (Philip Morris) & Argentina & $\mathbf{F}$ & 1455.7 & & $1795^{\circ}$ & $\ldots$ \\
\hline Nobleza Piccardo (BAT) & Argentina & $\mathbf{F}$ & 892.4 & & 1700 & $\ldots$ \\
\hline $\begin{array}{l}\text { Cigatam } \\
\text { Chemicals }\end{array}$ & México & DP & 672.4 & 18.4 & 3446 & $\cdots$ \\
\hline Celanese & Mexico & $\mathbf{F}$ & 1255.9 & & 6791 & 613.5 \\
\hline Basf & Brazil & $\mathbf{F}$ & 983.9 & & 4429 & 107.0 \\
\hline Grupo Irsa & Mexico & DP & 757.4 & & 4472 & - \\
\hline Bayer & Brazil & $\mathbf{F}$ & 574.3 & & 2555 & 192.5 \\
\hline White Martins Industriais & Brazjl & $\mathbf{F}$ & 542.6 & & 4503 & $\ldots$ \\
\hline $\begin{array}{l}\text { Computer and telephone } \\
\text { equipment }\end{array}$ & & & & 14.7 & & \\
\hline $\mathrm{IBM}$ & Brazil & $\mathbf{F}$ & 1950.0 & & 4039 & 136.1 \\
\hline IBM & Mexico & $\mathbf{F}$ & 1550.0 & & $\ldots$ & 1258.3 \\
\hline Hewlett-Packard & Mexico & $\mathbf{F}$ & 1141.9 & & 1045 & 365.8 \\
\hline NEC do Brasil ${ }^{\circledR}$ & Brazit & DP & 905.7 & & 2496 & - \\
\hline IBM & Argentina & $F$ & 630.0 & & 1200 & $\ldots$ \\
\hline Tyres & & & & 14.6 & & \\
\hline Goodyear & Brazil & $\mathbf{F}$ & 835.2 & & $\ldots$ & 212.4 \\
\hline Pirelli Prews & Braxil & $\mathbf{F}$ & 644.0 & & 4930 & 132.3 \\
\hline Bridgestone/Firestone & Brazil & $F$ & 617.0 & & $\ldots$ & $\ldots$ \\
\hline Tigre & Brazil & DP & 358.6 & & 2642 & - \\
\hline Alumininm & & & & 8.1 & & \\
\hline $\mathrm{CVG}^{\mathrm{c}}$ & Venezuela & $\mathbf{S}$ & 4000.0 & & 28000 & 1050.0 \\
\hline Alcoa Aluminio & Brazil & $\mathbf{F}$ & 1060.4 & & 8346 & $\ldots$ \\
\hline Albrás & Brazil & $\mathbf{S}$ & 518.1 & & $\ldots$ & $\cdots$ \\
\hline Caraita & Brazil & $\mathrm{DP}$ & 492.9 & & 944 & $\ldots$ \\
\hline Motor industry & & & & 0.0 & & \\
\hline Volkswagen & Brazil & $\mathrm{F}$ & 7003.3 & & 29616 & - \\
\hline Chrysler & Mexico & $\mathbf{F}$ & 6455.4 & & 11066 & 4948.3 \\
\hline General Motors & Mexico & $\mathbf{F}$ & 6345.6 & & 91263 & 4526.5 \\
\hline General Motcrs (GMB) & Brazil & $\mathbf{F}$ & 5432.9 & & 20800 & 611.6 \\
\hline Fiat & Brazil & $\mathbf{F}$ & 4742.9 & & 21359 & 329.9 \\
\hline Toiletry and deaning articles & & & & 0.0 & & \\
\hline Gessy Lever & Brazil & $\mathbf{F}$ & 2748.7 & & 9724 & 41.6 \\
\hline Avon & Brazil & $\mathbf{F}$ & 1222.3 & & 3500 & - \\
\hline Procter \&amble & Mexico & $\mathbf{F}$ & 1200.0 & & $\ldots$ & $\ldots$ \\
\hline Unilever & Argentina & $\mathbf{F}$ & 796.7 & & 2800 & $\ldots$ \\
\hline Total & & & 122270.5 & $39.8^{f}$ & 779686 & 24791.5 \\
\hline
\end{tabular}

Source: Chapter 1 of Peres, 1998.

- In some sectors fewer than five enterprises are listed because there were not sufficient enterprises in the sample or because some were etiminated in order to avoid duplication with holding companies. The individual enterprises in the sectors are ranked according to the shares of domestic enterprises in the sales of the five biggest firms; when the shares are equal they are ranked according to their toral sales.

bypes of ownership: DP: domestic private; F: foreign private; S: State-owned.

corresponds to a holding company; may include activities not related to the sector.

d Property of Cernex.

Enterprise controlled by Globopar, the holding company of Organizaçōes Globo.

$f$ Average weighted by the sales of the five largest firms. 
duction in the region was of the order of US\$750 billion and the level of industrial employment was close to 8.5 million persons. ${ }^{14}$ Domestic firms had a share of $39.8 \%$ in the sales of this universe.

Secondly, the table shows that the sectors where big domestic private enterprises had a clearly predominant share of the sales of the five biggest enterprises (over $66 \%$ of the total) corresponded to traditional activities producing mass-consumption goods or basic inputs (non-alcoholic beverages and beer, glass, petrochemicals, steel, textiles, agro-industries, cement, and pulp and paper) and to one metal products and machinery industry: the manufacture of motor vehicle parts. While the share of domestic enterprises in foodstuffs, machinery and equipment, ${ }^{15}$ household and electronic appliances and tobacco products ${ }^{16}$ stands at an intermediate level (between $30 \%$ and $66 \%$ of the total), they have little or no participation in some sectors making intensive use of technology and advanced marketing techniques, such as automobile production, the manufacture of computer and telephone equipment, tyres, chemical products, and toilet and cleaning articles. ${ }^{17}$ Although the privatization processes opened up some modern areas other than the industrial sector to the BIGs -such as telecommunications, where they have had to enter into associations with big transnational corporations in order to cope with the strong competition- they do not have an important share in technologically advanced manufacturing activities at the international level. ${ }^{18}$

\footnotetext{
${ }^{14}$ This employment figure does not include micro-enterprises.

${ }^{15}$ Due fundamentally to the output of Condumex, a Mexican company producing electric cables.

16 It should be noted that the sale of the 1wo biggest Mexican tobacco companies to foreign corporations in 1997 markedly reduced the share of domestic enterprises in this sector.

${ }^{17}$ Their share of the aluminium seclor is due to the high level of participation of two State-owned enterprises among the four biggest firms.

18 There are very few cases of the entry of Blos into high-lechnology industries, the most outstanding examples being the investments of the Pulsar Group (Mexico) in biotechnotogy and some cases of participation (sometimes only transitory) by Brazilian groups in joint ventures for the development of computer programmes and equipment or consumer electronic goods, generally originating while the reserved markets policy was still in force (Itautec, Philco, Semp Toshiba, Sharp, NEC, CCE da Amazónia, for example), Of the 46 big enterprises analysed indjvidually in this study, only one (Sonda, Chile) could be considered as specializing in a branch of technology typical of the present technological revolution (production of computer programmes).
}

The combination of sectoral specialization in relatively homogeneous goods involving large economies of scale, on the one hand, and sizes of enterprises which are small compared with their main competitors, on the other, make the BIGs somewhat vulnerable in terms of competitiveness, as we shall see later. Protectionism allowed some of these sectors to devote themselves to the production of goods which were practically not tradeable, so that their growth was totally determined by that of the domestic market. With the opening up of the region's economies, however, these sectors are facing growing global competition from world-level competitors who are smaller and smaller in number but increasingly powerful. As a result, the BIGs have lost the stability they previously enjoyed through being leaders in these traditional sectors and are facing the strategic challenge of either growing or being absorbed by big global corporations.

A third element that emerges from the table is the concentration of sectoral leadership in Mexican firms, which have the biggest sales in six of the eight sectors where domestic enterprises have a share of over $50 \%$ in the sales of the five biggest firms and register the biggest sales in the sector.

Finally, if we combine the information from table 3 and from chapter 1 of Peres (1998), we may conclude that there are BIGs where the conglomeration combines sectoral leadership with direct links with banks or other financial agents, thus further strengthening the advantages in terms of access to the capital markets that usually go with a large scale of operations. ${ }^{19}$ However, the financial-industrial linkage may also offer other forms of more open access to these markets, as may be seen from the case of highly successful groups which neither own banks nor belong to them, one of the most notable examples being Cementos Mexicanos (CEMEX).

\section{e) Relations between the domestic market and the international economy}

In order to conclude our profile of the BIGs, we may refer to the relations they have established between their domestic markets and the international market. As will be analysed in detail below, in response to the process of opening-up to external

\footnotetext{
${ }^{19}$ In this respect, it is useful to recall the classic works of Leff (1976, 1978 and 1979), in which it was argued that the Latin American economic groups were a response to the insufficient development of the capital markets of the region.
} 
competition the BIGs entered the field of non-traditional exports, in addition to the various strategies they used to defend their domestic market segments. In this way, they sought to expand their outside markets within their traditional regional spaces or those developed through integration and, in time, in the big markets of the industrialized countries too. Table 3 shows that, of the $\mathbf{4 1}$ domestic enterprises which belonged in 1996 to the group of the "top five" in 19 industrial sectors, 37 of them exported part of their production, although the sample does not register the corresponding amounts in all cases. In the sectors where domestic enterprises predominate, the proportion of exports in their total sales is particularly high in the case of agro-industries, pulp and paper production, steel and glass. If we consider only the 24 domestic enterprises for which export data are recorded, the average proportion of exports in the 19 industrial sectors is $23.6 \%$. Although this proportion is almost double the $13.1 \%$ they registered in 1994 , it is far below that of the foreign-owned enterprises in the sample $(33.9 \%)$ : a result which is strongly affected by the exports of the motor vehicle manufacturers.

One group of BIGs -usually the biggest oneshave internationalized their activities more fully, since they not only export goods but also capital, making direct investments abroad through the creation of new enterprises, the acquisition of existing firms, mergers or strategic alliánces. This internationalization takes two forms.

On the one hand, there is a regional-scope process associated with the consolidation of trade integration, such as the process displayed by the BIGs operating in MERCOSUR or in the framework of the North American Free Trade Agreement (NAFTA). In the first of these cases, noteworthy examples are the investments made in Argentina by the Chilean companies Enersis and Compañfa Manufacturera de Papeles y Cartones (CMPC) and Brazilian auto parts producers such as COFAB. In the second case, the most important investments have been those made by Vitro (Mexico) in the United States. ${ }^{20}$ So far, this second form has been more frequent.

\footnotetext{
${ }^{20}$ The attempts at internationalization by Latin American firms have had mixed results. Thus, the purchase of Anchor Glass, the biggest glass bottle maker in the United States, by Vitro in 1989 ended in failure seven years later. The strategic alliances and joint ventures thave also had yaried outcomes, and it is not unusual for them to last for only a short time and to be dissolved for various reasons.
}

On the other hand, a more complex form of internationalization is that carried out by enterprises which set up subsidiaries in various parts of the world in a coordinated manner and as part of a common strategy. These enterprises are seeking to become global players, and they are strongly influenced in this by the forms of competition prevailing in their industries: this was so in the case of producers of cement, soft drinks and beer, among others. The most important example in the region is that of CEMEX, with its investments in the United States, Spain, Central America and South America; indeed, its Mexican activities now come under those of its North American division.

The relative importance of these Latin American global enterprises, compared with other similar ventures which have arisen in developing countries, can be better appraised with the information from a 1995 sample of the 50 largest transnational corporations originating in developing countries (see UNCTAD, 1997). ${ }^{21}$ Among the enterprises studied, 13 were of Latin American origin; ${ }^{22}$ eight were from industrial sectors, four from petroleum and mining, and one from communications media. Among the eight industrial enterprises, five were Mexican, two were Brazilian, and one was Chilean.

Among the six largest Latin America enterprises, only one was industrial (CEMEX). Moreover, although this was the second largest industrial enterprise according to the value of its assets abroad, it only came in 26th place in the ranking by total sales, since CEMEX's sales were less than $10 \%$ of those of the biggest industrial group in the sample (Daewoo), which came to over US\$26 billion.

This information highlights once again the specialization of Latin American enterprises in areas closely linked with processed natural resources, in contrast with the concentration of the East Asian countries on activities such as the manufacture of electronic goods. At the same time, however, in spite of the limitations of this type of information it may be noted that, in terms of the index of transnationalization, ${ }^{23}$ the enterprises of the region have a similar average $(32 \%)$ to that of the Asian countries, excluding China.

\footnotetext{
2) The sample has limitations of coverage, so that the data from it should only be used indicatively.

${ }^{22}$ Similar data for 1993 registered the presence of 17 such Latin American enterprises (UNCTAD, 1995).

${ }^{23}$ The index of transnationalization is calculated as the average ratio of foreign assets to totat assets, of foreign sales to total sales, and of employment abroad to total employment (UNCTAD, 1997).
} 


\section{Business dynamics}

The BlGs have had to face various situations of change in the course of their history. Two past events were particularly important: $i$ ) the introduction of explicit import substitution industrialization policies in the 1930s, with their consequent impact on the dynamics of organizations which had arisen in the context of the agricultural or mining export model of previous decades, and ii) the exhaustion of those policies and the onset of the external debt crisis in the early 1980s. Today, they are going through an equally important period in which they are seeking to adjust to a less protectionist economic order, with strong competition in the goods and capital markets, in the midst of a technological revolution which appears to be speeding up still further.

The analysis of the present adjustment may be organized into three levels: i) the changes in the shares of the BIGs in the universe of big enterprises of the region; ii) the changes which have been taking place at the industrial enterprise and plant level, and iii) the dynamics of the general strategy of the groups to which these enterprises belong.

\section{a) Changes in the shares of domestic enterprises in the universe of big enterprises}

The available aggregated information shows that the big domestic enterprises have increased in size but have lost relative weight in the universe of (domestic and foreign-owned) large private industrial enterprises, subject to some reservations which will be explained later. This has been the result of the interaction of two important processes which have taken place in Latin America as a consequence of the structural reforms. The first was the privatization of State enterprises in the course of the 1980s and 1990 s, which has led to their virtual disappearance from the universe of big manufacturing enterprises in the region. The other was the growing presence of subsidiaries of foreign enterprises as a result of deregulation, easing of the rules limiting their presence in some specific sectors, and the policy measures taken in order to attract foreign capital. In spite of the active role that domestic enterprises played in the privatization process and in the defence of their local markets and expansion of their exports, they were not able to prevent the big increase in the presence of subsidiaries of foreign corporations.

The increase in size may be seen from table 4, which shows that the domestic enterprises in the uni- verse of the 100 largest industrial enterprises of Latin America increased their annual sales from an average of US\$ 827 million in 1990 to US\$1,345 million in $1996 .{ }^{24}$ In spite of this effort, however, they grew more slowly than foreign enterprises, which increased their average size from US\$1,075 million to US\$ 1,879 million over the same period. This table also shows that the share of domestic private enterprises in the sales of the 100 largest industrial enterprises went down from $45.9 \%$ to $40.2 \%$ between 1990 and 1996, while the share of State-owned enterprises went down to less than one-third of its initial level but that of the subsidiaries of foreign corporations grew significantly to $57.3 \%$ of the total. It must be borne in mind, however, that the enterprises of a single industrial sector -motor vehicle assembly- accounted for 30 percentage points of the share of foreign enterprises both in 1996 and in 1994 (in 1990 they accounted for $22.1 \%$ ). Thus, 8 of the 11 percentage points by which foreign firms increased their participation was due to the outstanding performance of that sector in the countries studied (Mortimore, 1997), and almost the whole of this increase occurred between 1990 and 1994.

Leaving aside what happened in the motor industry, however, the information in table 4 also points to other elements, since it shows that much of the decline in the share of domestic enterprises in the universe of the 100 biggest enterprises took place as from 1994, while the foreign enterprises operating in sectors other than the motor industry increased their share by almost four percentage points. The 1995 Mexican crisis and its negative impact on the other economies of the region (the "tequila effect") could mark a turning point in this respect. ${ }^{25}$ Not only may it be inferred that the lower propensity to export of the domestic enterprises compared with the foreign enterprises had a more adverse effect on them in view of the decline in the domestic market, but also that the information contained in the country studies presented in Peres (1998) shows the importance of the purchases of domestic firms by foreign corporations

\footnotetext{
${ }^{24}$ In the context of slow economic growth which marked the period in question, this increase in size suggests that the loss of the static rents which they enjoyed from protection was more than offset by their exploitation of the wider market provided through trade openness.

${ }^{23}$ In particular, the share of Mexican enterprises in the sample of the 100 biggest enterprises went down from $22.0 \%$ in 1994 to $19.5 \%$ in 1996 .
} 
TABLE 4

Latin America: Evolution of the 100

largest Industrial enterprises, 1990, 1994 and 1996

\begin{tabular}{|c|c|c|c|}
\hline Enterprises & 1990 & 1994 & 1996 \\
\hline \multicolumn{4}{|c|}{ Number of enterprises } \\
\hline Domestic private & 52 & 55 & 49 \\
\hline Foreign & 40 & 44 & 50 \\
\hline State-owned & 8 & 1 & 1 \\
\hline Total & 100 & 100 & 100 \\
\hline \multicolumn{4}{|c|}{ Sales (millions of dollars) } \\
\hline Domestic private & 43011 & 68269 & 65898 \\
\hline Foreign & 43009 & 80991 & 93953 \\
\hline State-owned & 7688 & 2757 & 4000 \\
\hline Total & 93708 & \multicolumn{2}{|l|}{ Average sales (millions of dollars) } \\
\hline Domestic private & 827 & 1241 & 1345 \\
\hline Foreign & 1075 & 1841 & 1879 \\
\hline State-owned & 961 & 2757 & 4000 \\
\hline Total & 937 & 1520 & 1638 \\
\hline \multicolumn{4}{|c|}{$\begin{array}{l}\text { Shares in the sales of the } 100 \text { largest } \\
\text { industrial enterprises (\%) }\end{array}$} \\
\hline Domestic private & 45.9 & 44.9 & 40.2 \\
\hline Foreign & 45.9 & 53.3 & 57.3 \\
\hline Motor industry & (22.1) & $(30.0)$ & (30.2) \\
\hline Others & $(23.8)$ & (23.3) & (27.1) \\
\hline Stals-owned & 8.2 & 1.8 & 2.5 \\
\hline Total & 100.0 & 100.0 & 100,0 \\
\hline
\end{tabular}

Source: Prepared by the authors on the basis of data from America Economia (1993, 1996 and 1997).

as from 1995. Outstanding in this respect, in the countries hardest hit by the "tequila effect", was the sale of stock holdings giving total or partial control of enterprises in the food industry in Argentina and in the beer and tobacco products industries in Mexico.

Nevertheless, however, industrial enterprises have also been sold out to foreign investors in countries, such as Chile, where the "tequila effect" was practically nil. In these cases, the foreign investors' interest in occupying positions in the narkets of those countries by purchasing existing companies may be due to the maturity of the globalization potential of the production sectors in question and the expansion of markets as a result of subregional integration in Latin America. This is shown by the fact that although some purchases involved enterprises with production or financial problems, such as the Brazilian automobile parts manufacturer Metal Leve, many of them corresponded to successful companies such as the electric power holding company Enersis in Chile or the three main Brazilian household appliance manufacturers, which were acquired by big transnational corporations between 1995 and 1997 (The Economist, 1997). b) Changes at the plant or enterprise level

At this level, the main changes have been in organizational, commercial and financial functions, the situation being more heterogeneous at the production and technological levels. Forms of business organization have tended to reduce the number of levels of anthority, leading to a less vertical structure, and have concentrated activities in business centres or units, markedly increasing the professional nature of management: a modemization process which has coincided in some cases with a change of generation in family-controlled businesses. Within this context, commercial functions and financial engineering continue to be the strongest areas of management.

With regard to marketing, there have been substantial changes in relations with clients and suppliers of services or inputs. The strengthening of a client-oriented approach (or an approach oriented towards the consumers or users of intermediate products) has made it possible in some cases to stand up to competition from imported goods. In other cases, it has been necessary to combine this approach with the importation of finished or intermediate goods in order to complete the product lines offered to clients 
and distributed through strong marketing channels set up during the import substitution industrialization era. ${ }^{20}$

While the relations with clients (especially endusers) and suppliers of production services have significantly improved as a result of the efforts to keep domestic customer loyalty and reduce operating costs, relations with suppliers of tradeable inputs present a more varied picture. The pressure from imports has made itself felt particularly in the replacement of domestic suppliers by those from abroad: a strategy which has been accompanied by the importation of finished goods for sale on the domestic market. In both cases, this has reduced the demand for domestic inputs: a phenomenon which has been matched, for similar reasons, by a much less highly developed domestic supply of capital goods. However, there have been extensive programmes to develop suppliers for some assembly industries, such as the assembly of computer equipment at Guadalajara (Mexico), or the automobile parts industries at Bahia (Brazil) and Cordoba (Argentina).

Traditional comparative advantages, ${ }^{27}$ accumulated capacities and macroeconomic policy seem to be the variables that determine the selection of one or the other of these approaches. Everything seems to indicate, at least in the short term, that the tendency towards an increase in the relative importance of imports of inputs and capital goods will predominate, except at times of macroeconomic adjustment with recession and abrupt devaluation of the exchange rate. This has led to the weakening of many local production chains and has reduced the options open to small and medium-sized supplier firms, as explicitly acknowledged, for example, in the Industrial Policy and External Trade Programme adopted by Mexico in 1996 (Peres, 1997).

\footnotetext{
${ }^{26}$ This has been so in the case of antomobile assembly firms (such as Fiat in Brazil or the Compafía Colombiana Automotriz (CCA) and the Sociedad de Fabricacion de Automotores (SOFASA) in Colombia), household appliance manufacturers (such as the Industria Colombiana de Electrónica y Electrodomésticos (INCELT) in Colombia or the Companta Tecno Industrial (CTI) in Chile), and even steel and petrochemicals enterprises such as Acerfas de Colonbia (Acesco) and Poliolefinas Colombianas (Policolsa).

${ }^{27}$ The strength of the systems of suppliers for the big agro-food groups in Brazil (Perdigäo and Sadia), Argentina (Moreno, Urqufa, Bunge y Born) and Chile (Industria Azucarera Nacional - IANSA) shows the importance of the comparative advantages base for promoting non-voluntaristic supplier development programmes. The limited competitiveness of the Colombian suppliers of barley for the Bavaria beer company shows the same thing in the opposite sense.
}

The product mix manufactured or marketed by firms has also changed, although not always in the same direction. While textile companies such as Fabricato and Coltejer in Colombia and São Paulo Alpargatas in Brazil have reduced their range of products, other types of companies have expanded it, as in the case of WEO Motores, Oxiteno (chemicals) and USIMINAS (iron and steel) in Brazil. Although there have also been some cases of expansion of the product mix of some Chilean companies (MADECO, for example), it would appear that the Brazilian companies mentioned have moved in this direction because of the size of their domestic market and the possibility of combining economies of scale and scope.

Even in the cases where companies expand their range of products, the tendency to subcontract with third parties to carry out secondary activities is a generalized response to the greater competition. Sometimes this subcontracting is accompanied by greater vertical integration of the industrial group itself, as we shall see below.

The strengthening of financial engineering in the big enterprises has allowed the BIOs to consolidate their access to short- and long-term international capital markets, their most notable operations being the issue of ADRs on the New York market. In a few cases, access to the capital markets has meant the complete opening-up of the firm's equity, but as already noted, family control continues to predominate.

The production and technological development functions of the enterprises have not generally developed as much as the marketing and financial functions. Among the enterprises of the three countries which were studied in detail, those of Brazil show the greatest interest and capacity in these areas, which is also consistent with other indicators, such as the number of Iso 9000 certifications obtained. Market size and the relative maturity of the existing capacities seem to be the main factors behind this better performance, especially with regard to product design, exploitation of brand names and quality management (Bonelli, 1997), effectively supported in some cases by pubiic policy. ${ }^{28}$

\footnotetext{
${ }^{28}$ The progress made in Brazil in the area of "soft" technologies is generally attributed to the success of the Brazilian Quality and Productivity Programme applied since 1990.
} 
In the other countries, advances in production and technology are relatively less marked. ${ }^{29}$ The main achievements in terms of increases in average labour productivity at the sectoral level -which were noteworthy in the first half of the 1990 s even after deducting the effect of the economic cycle (Katz, Benavente, Crespi and Stumpo, 1997)- are mainly attributable to reductions in the number of persons employed, as a result of the subcontracting of secondary activities; nore flexible working processes, and the incorporation of some elements of new management techniques. However, the individual country studies show that there were also substantial investments in the modernization of the plant and equipment of the big firms in some mature import substitution industrialization industries, such as the production of iron and steel in Argentina, sugar in Chile, beer in Colombia and cement in Mexico. The BIGs' abundant access to finance facilitated this response to the increased competition due to trade openness, in contrast with the position of smaller firms.

The different relative weights of the various management functions depend on supply and demand factors. The crisis of the 1980s caused the top management to centre their attention on marketing and finances, since the problems which they perceived to be most acute were the fall in sales and the inability of their firms to meet their financial obligations. In due course, this demand gave rise to a supply of highly qualified professionals in these areas. Matters of production and technology were relegated to the background: an approach which was often strengthened by the importation of capital goods requiring little or no adaptation, which increased considerably with the economic recovery of the early 1990 s.

\section{c) Growth strategies}

The changes which have taken place in the strategies of the Blos may be grouped in various ways, but in general they tended to be centered on the triad of withdrawal, defensive and offensive strate-

\footnotetext{
${ }^{29}$ Even in the case of Chile, the relevant chapter of Peres (1998) notes that although that country occupied ninth place in the "business management" ranking of the 48 countries listed in 1996 in the World Competitiveness Report (IIMD, 1996), it dropped to 27 th place when the "science and technology" factor was included.
}

gies, ${ }^{30}$ although the first two of these imply, in the long term, the cessation of activities or loss of control of the firm by its original owners. In all cases, the strategies could be either a reaction to outside pressures (reactive strategies) or they could be basically proactive.

The universe of BIGs displays all three of these types of strategies, although, because of their size, the examples of withdrawal tend to be concentrated in the category involving the sale of the whole enterprise or a controlling interest to foreign investors, rather than its closure; examples of this are the Astra petroleum group in Argentina, the COFAP auto parts firm in Brazil, and the two big cigarette manufacturers in Mexico: Cigarros La Tabacalera Mexicana (CIGATAM) and La Moderna.

Defence of the domestic market has taken different forms, the most important ones being preventive investments (especially in the two biggest economies); the importation of finished products for sale on the domestic market, taking advantage of local distribution networks; greater and more intensive orientation of activities towards the client (especially noteworthy in the food industries); the formation of combined industrial and financial groups, in countries where this is permitted by law; ${ }^{31}$ and rent-seeking through access to fiscal, trade or sectoral promotion benefits. Although these latter benefits are less prevalent than in the past, they are still far from having disappeared completely, as shown by the examples of the motor industry in Argentina, Brazil and Mexico, forestry in Chile, or the support given to various industrial sectors in Colombia.

\footnotetext{
${ }^{30}$ Naturally, defensive strategies do not make much sense in the long run. In the face of greater competition and ongoing technological change, a defensive strategy can only be a stage on the way to withdrawal ot to an offensive strategy. Experience also shows that there is no need for a preliminary defensive stage, since many of the biggest firms have followed an offensive strategy ever since the beginning of the external debt crisis. Restructuring of assets (mergers and acquisitions), investments abroad and closer links with the financial sector developed throughout the 1980 s, although they were combined with strategies to defend the domestic market share when trade openness began to be applied.

${ }^{31}$ Among the countries studied, Chile displays the lowest degree of formal linkages between banking and industry, because of the experience of the crisis of the earty 1980s, although some of its industrial groups do have clear links with banks. Also, both in Chile and Brazil there is growing participation by pension funds (private, in the case of Chile; belonging to big State enterprises, in the case of Brazil) in the equity of the biggest enterprises. This could open up new ways of promoting finance-based conglomeration.
} 
One form of defensive strategy which has been used (although it involves new diversified investments) is the shift from industrial activities to modern non-tradeable services. The tendency to move out of industrial sectors is the result of signals coming from the trade openness process and macroeconomic policies which maintain an overvalued national currency that adversely affects the profitability of the tradeable goods sectors. The possibility and desirability of investing in non-tradeable services has also been furthered by the deregulation of some markets or the privileged access that some groups have had, or hope to have, to the privatization of telecommunications, electricity distribution, and the infrastructure in general. In many cases, as seems clear in Colombia, this approach has led groups to use their big industrial enterprises as a source of financial tesources for taking part in privatization operations or deregulated markets, while putting off or minimizing their investments in the modernization of production activities.

In this sense, one might wonder to what extent the structural reforms have done away with the rentseeking behaviour of major sectors of the business world, since although some markets for nontradeable services are hotly disputed between strong competitors, the conditions of that competition and, hence, the final profitability of the activities in question, depend on State regulations and the differential access of the competitors to the market.

Offensive strategies are more complex, and at least three different types may be distinguished:

i) Growth with increasing specialization around the basic core business, as in the case of some BIGs strongly centered around the processing of natural resources, such as Bunge $y$ Born and Pérez Companc in Argentina, Klabin in Brazil or Alfa in Mexico. This category also includes BIGs which have not increased their degree of specialization because it was already very high, such as CEMEX in Mexico and the Matte Group in Chile.

ii) Growth with moderately increased diversification, possibly combining de-verticalization at the level of individual enterprises with an increase in vertical or horizontal integration at the level of the group as a whole, as a result of participation in a few privatization operations, mergers, or acquisition of other private companies. In all cases, the basic criterion for engaging in this type of operations is the achievement of potential synergies. Techint and
Pescarmona in Argentina, Angelini in Chile, Suzano and Votorantim in Brazil, Santo Domingo (Bavaria) in Colombia and Pulsar in Mexico are examples of this type of moderate strategy.

iii) Growth with extreme diversification, largely as a result of participation in numerous privatization operations. These cases, which give rise to true conglomerates without any clear production, commercial or even financial synergies, are often due to the adoption of portfolio-based criteria. The most notable examples are the Sociedad Comercial del Plata (energy, construction, services) in Argentina, Vicunha (textiles, iron and steel, mining) in Brazil, and Carso (telephone services, electric cables, tyres, restaurants) in Mexico. These conglomerates cover extremely dissimilar activities and their great relatively recent development is based on close links with the international capital market, the main domestic banks, and the decision-making circles at the political level of privatization operations. Naturally, the expected gains and the financial risks are both high.

In each particular case, the strategies adopted depend on a complex set of factors. The sectoral factor is generally important at three levels: i) the different competitiveness of each sector and hence its capacity to compete with imports in a context of trade openness; ii) its different degree of maturity, due to its particular learning curve and degree of progress; and iii) the relevant promotional policy packages, which, although often not openly acknowledged, have been important in almost all countries (petrochemicals in Argentina, forestry in Chile, and the motor industry in Mexico and Brazil are some notable examples). The sectoral factor alone is not sufficient to explain the business strategy adopted, however, as is shown by the studies of pairs of Blos located in the same sectors in Brazil (Peres, 1998).

Thus, the iron and steel groups (Gerdau and Belgo-Mineira) took different approaches to buy-outs and privatization operations. Although Klabin and Suzano compete in the pulp and paper market, the former sought to specialize, while the latter showed more interest in moderate diversification. Finally, there could hardly be a greater contrast than in the case of the textile groups, since whereas Alpargatas took a basically defensive strategy, Vicunha (which was based on very strong financial support) ended up as a major participant in the Companhia Siderúrgica Nacional and in the mining giant Companhia do Vale do Rio Doce. 
The caution or boldness of the business leadership, though difficult to define, are important factors in explaining the final adoption of a strategy. These differences in management styles, which are relaively independent of the systemic determinants, would also explain the different preferences of the groups with regard to privatization operations, ranging from little or no participation to an overwhelming presence both in the home country and abroad. Naturally, the style of management and the quest for economic power are often inseparable in operational terms. Beyond these differences, however, an element which is shared by the different strategic options is the growing weight of the external market, whether in exports or in imports, and whether it is a question of receiving or of making foreign investments.

In short, the growth of the successful BIGs has not been merely the result of repeating a tried recipe. On the contrary, in order to develop in the product lines in which they already had experience they have had to make big changes in their organization, marketing techniques and finances, as well as investments in new plants and modern equipment. Even so, some of the elements analysed in the following section suggest that staying within their traditional prodvet lines may restrict their long-term giowth, so that in the future they will probably have to face up to the need to shift their growth paths towards more dy. namic sectors.

\section{IV}

\section{Challenges and policy responses}

The current profile of the BIGs is itself a proof that a significant number of them have made a positive shift within the framework of the structural changes that have taken place over the last decade. The results are still limited and changing, however, because this class of enterprises, together with the sectors and the economies in which they operate, are still in a state of change, subject as they are to internal tensions and the pressure of international competition.

The present situation of the BIGs reflects successes in consolidating their growth paths, successfully coping with the dynamics of the industries in which they operate, and taking advantage of the support offered by public policies. However, they are faced with challenges due to the limits imposed by their sectoral specialization and the contradictory signals emerging from the interaction of the structural reforms and the macroeconomic policies which have accomparied them.

\section{The limits of sectoral speclatization}

In the long term, the continued presence of BIGs in product lines that are not drawing closer to those registering high growth rates in the world market suggests that they may eventually run out of further growth possibilities. Although in the short term some traditional product lines have registered strong growth which has served as the basis for the growth strategies of such enterprises, this has been influenced by elements which may not always favour their growth in the long term, ${ }^{32}$ if the most dynamic international trade flows continue to be concentrated in the products of the electronics and advanced engineering industries and natural resources continue to lose ground (Mortimore, 1995). ${ }^{33}$

The expansion of BIGs through their traditional product lines regularly leads us to discover that, in order to keep up their growth, they must expand their markets abroad. In order to do this, they must confront big transnational corporations which are not only competing in the same world markets but are also trying to take over the domestic markets of the

\footnotetext{
${ }^{32}$ As shown by the vegetable oils, forestry, fishery, mining and other industries, the increased output of these goods has been based mainly on strong expansion of their production frontier through investments in physical facilities and know-how. There are no generally accepted forecasts, however, regarding the possibility of maintaining in the long term the growth rate that this frontier has displayed in recent decades, even if demand for such goods continues to grow.

${ }^{33}$ Although it could be argued that it is not possible to draw a distinction between good and bad types of sectoral specialization, differences in the income-elasticity of world demand, returns to scale and learning paths make it doubtful whether all sectors are equally good for the long-term growth of an economy. See, in this respect, Cohen and Zysman (1987).
} 
BIGs. They are therefore faced with the following dilemma: whether to make changes in their strategies, forms of organization and production, finance, marketing and world market position in order to take on the global competition, or whether, on the contrary, to try to improve their current position in order to increase the value of their enterprises so as to sell them to their foreign competitors for the best possible price, taking advantage of the possible temporary over-valuation of their countries' national currency.

The first of these options requires extraordinary financial, technological and marketing resources, whereas the second option is increasingly frequent in the region, giving rise to growing foreign takeovers of the most dynamic segments of local industry ${ }^{34}$ The relatively small size of the BIGs compared with the world leaders and even with similar enterprises of some East Asian countries makes them an easy prey for hostile takeovers once their national or regional markets become attractive.

The option of selling the company opens up a series of opposing alternatives for the owners of the big Latin American companies. On the one hand, the sale may convert them into mere portfolio investors, but on the other, the liquid capital thus obtained may help them to move into new areas of investment. These moves follow two different rationales. In some cases, as already noted, the money obtained is invested in the production of non-tradeable goods and services (public utilities, privatized firms enjoying special protection regimes, etc.), in the expectation of preserving niches protected from foreign competition. On the other hand, however -particuiarly when the vendor possesses other enterprises with "specific secondary assets"- this may lay the foundations for a new long-term expansion path. ${ }^{35}$

\footnotetext{
34 Although foreign takeovers are not a problem in themselves, they make it more difficult to apply policies based on consensussecking between the public and private actors, as is increasingly the practice in Latin American countries (Peres, 1997). Acceptance of the explicit participation of external agents in the design and implementation of public policies would mean major changes in the potitical and cultural framework of most of the countries of the region.

${ }^{39}$ An example of this is the Pulsar group in Mexico, which sold its tobacco company La Moderna to the British-American Tobacco Company (BAT) for US\$ 1.7 billion in order to obtain resources to strengthen its biotechnology seed company, which is only small but is a world leader in its sector and will, it is hoped, be the basis for the group's development in the areas of agro-industry and forestry.
}

\section{The impact of the structural relorms}

The structural reforms sought to create a new pattern of competition, more open to the exterior and with less State intervention. In general, after a first period of relative moderation and gradualism, they became more intensive and even, in some countries, quite radical. In this context, the BIGs, which had been the great beneficiaries of the import substitution industrialization model, were seen in theory as obstacles to the establishment of a system of free competition, in view of their domination of important oligopolistic markets. In actual fact, however, the form taken by the structural reforms and explicit promotion measures gave rise to an economic order which was highly favourable to the development of the BIGs.

In addition to direct support through fiscal subsidies for some of the activities in question, four types of policies played an important role in this respect:

i) Privileged access to the main privatization operations, which were hardly ever carried out under free market conditions. In particular, the bodies responsible for the privatization were allowed to select the future groups that would control the privatized enterprises and to embody highly discriminatory conditions of access and future operation in the tendering rules. Indeed, there are indications that in some cases members of the privatization bodies or even of higher political levels were actors and beneficiaries in the tendering process.

ii) The international trade negotiations for the formation of free trade areas, as was perfectly desirable, gave the private sector an important role in participating in or advising on the definition of production sectors or policy practices which were particularly sensitive matters for each country, where greater openness could represent either a threat or an opportunity. However, the natural heterogeneity of the private sector meant that this participation was controlled in effect by the BIGs or the chambers of industry in which the BIGs played a decisive role.

iii) The implementation of the legislation designed to strengthen free competition through deregulation tended to maintain the status quo as regards the concentration of the various industrial branches, on the perfectly correct grounds that in open economies market power is not determined by the existence of a concentrated industrial structure. The view that the right thing to do was to avoid any actions militating against competition rather than to 
obviate concentrated structures was functional in maintaining the BIGs' shares in their key markets.

iv) Some promotional programmes aimed at non-industrial sectors also had a positive impact on the BIGs, especially in Mexico, where the demand generated by big highway and housing construction projects aided civil engineering enterprises such as ICA and producers of cement and flat glass (CEMEX and Vitro), which were important components in the main Mexican groups. The greater economic weight achieved by the big civil engineering and heavy engineering enterprises (empreiteiras) in Brazil was also due to this rationale.

In short, the new economic order operated in such a way that although the BIGs were oligopolies which had mostly arisen in the conditions of protection established under the import substitution industrialization process, it was nevertheless highly functional for their growth.

The studies included in Peres (1998) show that these groups have indeed been able to process the signals given by the new economic order in an effective manner. However, some incoherencies in those signals have hindered the materialization of the results which were expected from an export-led form of development which could link up efficiently with the rest of the industrial structure, and not just the leaders.

On the one hand, external openness has meant macroeconomic policies determined by the availability of the short-term international capital which is a key factor in financing the deficit that accompanies such openness. In this context, the free movement of capital and the over-valuation of the local currencies caused by the high real interest rates in dollars, the contraction in public expenditure and the containment of real wages are the "anchors" of the macroeconomic balances, especially price stability.

The result of this is that the signals enitted by the macroeconomic environment are contradictory, because although there is stability in the short term, the conditions in which this stability is achieved give rise to uncertainty, financial speculation and an increase in the expectations of future instability. ${ }^{35}$ Thus,

${ }^{36}$ A further factor which complicates this situation is that some of the key factors governing short-term capital flows are not under the control of national governments, as was shown by the crises in Mexico (1994) and Thailand (1997). the key variables of macroeconomic policy tend to weaken what should be the core of a new growth model: efficient international linkages through exports, especially of products with growing local added value. The ambiguous and confused signals transmitted by the main macroeconomic variables favour and continually increase the emphasis placed by enterprises on short-term considerations, which is unfavourable for a really sound restructuring process and for long-term competitiveness.

At the same time, the signals emitted by the structural reforms were insufficient. As noted earlier, these reforms -in spite of the importance they assigned to competition among the private actors - did not take due account of the actual problems of enterprises. On the contrary, the reform strategies made the structure of relative prices determined in free markets the key variable for giving the economic agents the information they needed in order to take their consumption and production decisions and, hence, ensuring that the economy would follow a path of sustained growth.

In these strategies, no attention was given to the design of policies to facilitate changes by entrepreneurs in response to the reforms. On the contrary, it was considered that the State should facilitate faster and more radical business adjustments by refraining from direct intervention and allowing the application of what was known at the time as "shock therapy", which was supposed to minimize the costs of change and establish suitable conditions for enterprises to promote sounder growth of the economy on the basis of the market rationale.

The failure to take account of the differences between individual enterprises and the many factors determining their behaviour suggests that the reforms were implicitly based on the idea of a form of competition determined by the relative power of the enterprises concerned, in which the biggest enterprises would in principle be in a privileged position to adapt to the macroeconomic and sectoral changes. Consequently, it may be asserted that an important component in the reforms was an ideological discourse (in the positive sense of the term) aimed at pronoting the restructuring of the BIGs and their assumption of a new but still predominant position in the new national and international conditions.

In keeping with this approach, the first stage of the reforms generally rejected active industrial policies and any financial, technological or organiza- 
tional strategy aimed at systematically promoting the restructuring and re-articulation of the various segments and sectors of activity towards a new type of organization of production capable of generating a dynamic of systemic competitiveness. In the second stage, in the mid-1990s, there has been a marked recovery of interest by the governments of the region in developing industrial competitiveness policies, although their political will and capacity for action in this respect are still weak (Peres, 1997). All this has limited the attempts to create business strategies that seek new paths for the expansion of production.

\section{The issues In the policy debate}

Together, the contradictory conditions within which the changes in the enterprises interact with the "selection environments" formed by the production patterns and the public policy contexts mean that the processes of change are taking place in an unstable manner, even for the successful BIGs, and involve costs, risks and delays for the economies where they operate. This is because these processes are not helping to generate a new economic fabric which is clearly viable in the long term. Everything suggests that it is necessary to reconsider some elements of the fundamental conception of the structural reforms if it is desired to achieve the progressive linking up of changes in enterprises, in the production pattern and in public policies in order to follow an efficient development path under the new international conditions. In this context, there are four policy areas which merit special attention, since they will form part of the future debate in the region:

i) The linkages between the financial and industrial sectors are the first area of unsolved problems, in spite of the different solutions that have been tried, ranging from de facto recognition of the operation of financial-industrial groups to the total separation of these two sectors for reasons of banking safety and prudence. In the first case, however, it has not been possible to obviate opportunistic or downright corrupt behaviour, with its consequent costs in terms of public confidence and expenditure, while in the second case there are obvious difficulties in inducing the banking system to progress in the financing of production activities related with the development of new sectors and technologies.

ii) The relative size of the BIGs is a second area of unsolved problems. Although, on the one hand, large size and growth may endanger free competition and increase structural heterogeneity, on the other hand most of the BIGs are too small by intemational standards to have much chance of succeeding against the great world-level oligopolistic industries. Moreover, this relatively small size has made them vulnerable to buy-outs by foreign investors from both inside and outside the region. Although this might not be very important ox might even be positive in terms of the growth and technical progress of the enterprises, it raises problems when trying to design concerted policies, because of the difficulty of openly including outside agents in the processes of negotiation and implementation of domestic policies, to say nothing of the strictly political dintension of the loss of national control over still more leading agents of development.

iii) We have seen throughout this article that openness, trade integration, accumulated capacities and the sectoral dimension are the main determinants of business strategies. With regard to the first two elements, the countries of the region have already adopted clear and in some cases irreversible positions, although some important decisions regarding timing and tempos are still outstanding. There is still a lack of decision at the sectoral level, however, and there is a lack of will to commit the necessary resources for the formation of competitive capacity. The lack of decision on how to act at the sectoral level in a context of markedly reduced protection may persist for a long time, and it may be that only isolated actions will be taken to meet needs associated with competition for foreign investments, the rescue of some sectors which are in crisis and, in the biggest countries, efforts to deconcentrate economic activity. However, there is no reason or valid excuse not to advance in the implementation of the many competitiveness policies designed in recent times in the region (Peres, 1997).

iv) Increasing the linkages of the BIGs with the rest of the enterprises is perhaps the most important problem to be solved in onder to ensure stable longterm development. Although the progress made has been only modest and there are even some cases of serious setbacks, the tendency towards the delinking of secondary activities will continue to be strongly pursued in the process of seeking greater competitiveness. The first reaction has been to use imports as a source of inputs and capital goods, but the pursuit of competitive advantages may cause attention to be 
directed to the possible comparative advantages of domestic small and medium-sized enterprises as suppliers of parts, components and services for production activities. The same political will that could boost the implementation of the competitiveness policies referred to earlier is very necessary in this area too. However, this political will is subject to the limits imposed by the specialization of the BIGs in sectors processing natural resources, where it is difficult to develop such long subcontracting chains -that is to say, chains with as many levels of small and medium- sized subcontractors- as those which exist in the assembly industries (for example, the consumer electronics, clothing or motor industries) ${ }^{37}$

Advancing in these policy aspects will require major efforts in terms of studies and proposals. The country studies which served as the basis for this article provide abundant material for reflection and for the design of action proposals designed to integrate the macroeconomic, sectoral and microeconomic factors that affect the business world in Latin America.

(Original: Spanish)

\section{Bibliography}

América Economia (1993): Base de datos sobre las mayores 1000 empresas en América Latina, 1990 1992, Mexico City, Nabei Ltd.

(1996): Las 500 mayores empresas de América Latina. Edición 1996/97, Mexico City, Nabei L.td.

(1997): Las 500 mayores empresas de América Latina. Edición 1997/98, Mexico City, Nabei Ltd.

Arbelaez, H. (1997): Economic Groups and Globalization in Colombia, Middletown, PA, Pennsylvania State University, School of Business Administration.

Bisang, R. (1996): Perfil tecnoproductivo de los grupos económicos en la industria argentina, in $\mathrm{J}$. Katz (ed.), Estabilización macroeconomica, reforma estructural y comportamiento industrial. Estructura y funcionamiento del sector manufacturero latinoamericano en los años 90, Buenos Aires, Alianza Editorial.

Bisang, R., G. Burachik and J. Katz (eds.) (1995): Hacia un nuevo modelo de organización industrial. El sector industrial argentino en los años 90 , Buenos Aires, Economic Commission for Latin America and the Caribbean (ECLAC)/Alianza Editorial.

Bonelli, R. (1997): Política industrial en Brasil: intención y resultados, in W. Peres (ed.), Poltiticas de competitividad industrial. América Latina y el Caribe en los años noventa, Mexico City, Siglo XXI Editores.

Cohen, S. S. and J. Zysman (1987): Manufacturing Matters. The Myth of the Post-Industrial Economy, New York, Basic Books.

Granovetter, M. (1994); Business groups, in N. Smelser and R. Swedberg (eds.), Handbook of Economic Sociology, chap. 22, Princeton, NJ, Princeton University Press.

IIMD (International Institute for Management Development) (1996): The World Competitiveness Report 1996. Lausanne, Switzerland.
Katz, J. (ed.) (1996): Estabilización macroeconómica, reforma estructural y comportamiento industrial: estructura y funcionamiento del sector manufacturero latinoamericano en los años 90, Buenos Aires, Alianza Editorial.

Katz, J., J. M. Benavente, G. Crespi and G. Stumpo (1997): New problems and opportunities for industrial development in Latin America, Oxford Development Studies, vol. 25, No. 3, Oxford, U. K.

Koike, K. (1993): Introduction, The Developing Economies, Special Issue on Business Groups in Developing Countries, vol. XXXI, No. 4, Tokyo, Institute of Developing Economies, December

Leff, N. (1976): Capital markets in the less developed countries: The group principle, in R. McKinnon (ed.), Money and Finance in Econonic Growth and Development, New York, Marcel Dekker.

(1978): Industrial organization and entrepreneurship in developing countries: the economic groups, Economic Development and Cultural Change, vol. 26, No. 4, Chicago, IL, The University of Chicago, July. (1979): Entrepreneurship and development: The problem revisited, Journal of Economic Literature, vol. XVII, No. 1, Washington, D. C., American Economic Association, March.

Mortimore, M. (1995): Paths Towards Intemational Competitiveness: A CANalysis, "Desarrollo productivo" series, No. 25, Santiago, Chile, ECLAC.

\footnotetext{
${ }^{37}$ As the structural reforms did not take into account the enterprise and sectoral dimensions, they failed to foresee the negative effects of the absence of linkages between the growth led by the BIGs and that of the small and medium-sized enterprises in terms of job creation and concentration of economic power.
} 
(1997): Dimensions of Latin American Integration. The NAFTA and MERCOSUR Automobile Industries, Santiago, Chile, ECLAC.

Paredes, R. and J.M. Sánchez (1996): Grupos económicos y desarrollo: el caso de Chile, in J. Katz (ed.), Es. tabilización macroeconómica, reforma estructural y comportamiento industriat. Estructura y funcionamiento del sector manufacturero latinoamericano en los años 90, Buenos Aires, Alianza Editorial.

Peres, W. (ed.) (1997): Políticas de contpetitividad industrial. América Latina y el Caribe en los años noventa, Mexico City, Siglo XXI Editores.
(1998): Grandes grupos y empresas industriales latinoamericanos. Expansión y desafios en la era de la apertura y la globalización, Mexico City, Siglo XXI Editores.

The Economist (1997): Back on the pitch. A survey of business in Latin America, London, 6 December.

UNCTAD (United Nations Conference on Trade and Development) (1995): World Investment Report 1995. Transnational Corporations and Competitiveness, Geneva.

(1997): World Investment Report 1997. Transnational Corporations, Market Structure and Competition Policy, Geneva. 